\title{
Changes in Sex Steroids and Ovarian Steroidogenic Enzyme mRNA Levels in Artificially Maturing Japanese Eel (Anguilla japonica) and Naturally Maturing New Zealand Longfin Eel (Anguilla dieffenbachii) during Vitellogenesis
}

\author{
Hajime Matsubara ${ }^{1, *(1)}$, P. Mark Lokman ${ }^{2}$, Yukinori Kazeto ${ }^{3}$, Hiromi Okumura ${ }^{4}$, Shigeho Ijiri ${ }^{4}$, \\ Toshiaki Hirai ${ }^{5}$, Graham Young ${ }^{6,7}$, Shinji Adachi ${ }^{4}$ and Kohei Yamauchi ${ }^{1,4}$ \\ 1 Noto Center for Fisheries Science and Technology, Kanazawa University, 11-4-1 Ossaka, Noto-cho, \\ Ishikawa 927-0552, Japan \\ 2 Department of Zoology, University of Otago, P.O. Box 56, Dunedin 9054, New Zealand; \\ mark.lokman@otago.ac.nz \\ 3 Research Center for Aquatic Breeding, Fisheries Research Agency, National Institute of Aquaculture, Tsuiura, \\ Kamiura, Saiki, Oita 879-2602, Japan; kazeto@fra.affrc.go.jp \\ 4 Division of Marine Biosciences, Graduate School of Fisheries Sciences, Hokkaido University, \\ 3-1-1 Minato cho, Hakodate, Hokkaido 041-8611, Japan; hokumura@chiome.co.jp (H.O.); \\ ijiri@fish.hokudai.ac.jp (S.I.); s-adachi@fish.hokudai.ac.jp (S.A.); y.kohei.0904@gmail.com (K.Y.) \\ 5 Faculty Agriculture/Sanriku Fisheries Research Center, Department of Food Production \& Environmental \\ Management, Iwate University, 3-75-1 Heita, Kamaishi, Iwate 026-0001, Japan; thiraisf@iwate-u.ac.jp \\ 6 School of Aquatic and Fishery Sciences, University of Washington, Seattle 98195, WA, USA; \\ grahamy@u.washington.edu \\ 7 Center for Reproductive Biology, Washington State University, Pullman 99164, WA, USA \\ * Correspondence: matsu@se.kanazawa-u.ac.jp; Tel.: +81-768-74-1080
}

Received: 18 September 2019; Accepted: 12 October 2019; Published: 17 October 2019

\begin{abstract}
Repeated hormone injections are routinely used to induce advanced stages of oogenesis in freshwater eels, but this approach may result in aberrant germ cell development. To investigate the underlying causes, levels of sex steroids (testosterone, T; estradiol-17 $\beta$, E2) and ovarian steroidogenic enzyme mRNAs were compared between artificially maturing Japanese eels and wild-caught, spontaneously maturing New Zealand longfin eels. The latter were employed as reference, as wild Japanese eels in advanced stages of oogenesis are near-impossible to catch. Serum T levels in artificially maturing Japanese eel changed with stage in a pattern that was comparable to that in longfin eels. Likewise, ovarian mRNA levels of most steroidogenic enzyme genes were not qualitatively dissimilar between both eel species when taking developmental stage into account. However, aromatase (cyp19a) mRNA levels, together with serum E2 levels, rapidly increased in artificially maturing Japanese eels in mid-late stages of oogenesis (gonadosomatic index, GSI $=13.8 \%$ ), whereas no such increase was evident in longfin eels (GSI 6.9\%). In addition, sex steroid and target gene mRNA levels fluctuated drastically with each hormone injection. We contend that expression of most target genes, possibly even that of cyp19a, during induced oogenesis could be "normal", with the drastic fluctuations due most likely to hormone delivery through repeated injections. The effects of these fluctuations on gamete quality remain unknown and resolving this issue may prove fruitful in the future to further artificial propagation of anguillid eels.
\end{abstract}

Keywords: eel; ovarian development; steroidogenic enzyme 


\section{Introduction}

In female vertebrates, gonadal development proceeds under gonadotropic hormone (GTH) control, and gonadotropic actions are mediated by sex steroid hormones mainly secreted by somatic follicular cells surrounding the oocytes [1-3]. A class of sex steroid hormones, estrogens (especially estradiol-17 $\beta$, E2) are well-known for their role in stimulating the synthesis of yolk protein precursor (vitellogenin) by the liver [4]. Vitellogenin, which is secreted into the bloodstream, is selectively incorporated into the oocytes, greatly contributing to oocyte growth $[2,5]$. After completion of oocyte growth, the diploid oocyte will resume the first meiotic division in response to a maturation-inducing steroid $[1,6]$, typically the teleost-specific progestin $17 \alpha, 20 \beta$-dihydroxy-4-pregnen-3-one, to give rise to a fertilizable oocyte.

Steroid hormones are produced from cholesterol by a suite of steroidogenic enzymes [1]. Sex steroid profiles and activities of steroidogenic enzymes throughout the natural reproductive cycle have been reported in many female teleosts. Furthermore, during the last 20 or so years, cDNAs encoding steroidogenic enzyme genes have been isolated from several fish species and their steroidogenic abilities evaluated after transient expression in vitro; early studies include those on P450 cholesterol side-chain cleavage (cyp11a) [7,8], 3ß-hydroxysteroid dehydrogenase (hsd3b) [9,10], P450 17 $\alpha$-hydroxylase/C17-20 lyase (cyp17a1) [11,12], 17ß-hydroxysteroid dehydrogenase type I (hsd17b1 ) [13], and the ovarian form of P450 aromatase (cyp19a) [14,15]. More recently, an additional cyp17 cDNA (cyp17a2) that does not display C17-20 lyase activity has been cloned from several fish, including tilapia, Oreochromis niloticus [16], and eel, Anguilla japonica [17].

To date, the relationship between mRNA levels of steroidogenic enzymes and steroid hormone levels in blood serum throughout the natural reproductive cycle has been documented in several fish species, including channel catfish Ictalurus punctatus [18], zebrafish, Danio rerio [19], rainbow trout, Oncorhynchus mykiss [20], and European seabass, Dicentrarchus labrax [21].

Cyp11a, cyp17, and cyp19a mRNA levels largely correlated with E2 levels in catfish and seabass, but less so in rainbow trout; in zebrafish, the relationship between plasma E2 levels and steroidogenic enzyme gene expression is more difficult to expose, given the asynchronous spawning strategy used by these fish-the cyp19a gene expression profile showed a peak in small oocytes (Stage II: 0.14-0.34 mm) [19] seemingly somewhat earlier than that seen in catfish [18], trout [20], or seabass [21]. However, steroid hormone levels in blood of female fish are likely to crudely reflect ovarian steroidogenic enzyme gene expression at large during the natural reproductive cycle.

In the last decade, the spawning area of the Japanese eel (A. japonica) was discovered [22] and mature female and male Japanese eels were captured near the West Mariana Ridge [23]. However, very little is known about the spawning ecology of these fish. Besides, freshwater eels never become sexually mature in captivity and hence, artificial induction of oocyte growth and maturation has been attempted using exogenous hormones, such as salmon pituitary homogenates (SPH) containing GTH [24]. In Japanese eel, the titer of steroid hormones and the activities of steroidogenic enzymes do not increase without such exogenous hormone treatment [25]. Indeed, gonadotropin treatment appears to be a prerequisite for the induction of advanced stages of oogenesis in anguillids [26].

Interestingly, steroidogenesis in artificially maturing female eels appears to proceed differently to that in naturally maturing non-anguillid female fish; for example, weekly injections of GTH rapidly, but temporarily, elevate the levels of several steroid hormones, which decrease a few days later. Thus, levels of circulating steroids are markedly different in artificially maturing eels from those in other female teleosts; moreover, $17 \alpha, 20 \beta$-dihydroxy-4-pregnen-3-one is typically not detectable at the maturational stage [27]. These differences quite likely reflect prolonged exogenous hormone treatment rather than differences in taxa per se [28]. This notion is reinforced by the fact that the survival rates of artificially produced larvae have been typically low [29,30] and that polyploidy [31] and deformities [32,33] are widespread among artificially produced larvae, despite advances made in the last 20 years or so [34]. In light of these observations, prolonged exogenous hormone treatment is likely to induce ovarian development that may not closely match the situation in wild conspecifics. Unfortunately, this 
prediction cannot be tested, as wild conspecifics in vitellogenic or later stages of oogenesis are virtually inaccessible to science.

Wild migratory New Zealand longfin eels, A. dieffenbachii, are more accessible and further advanced in terms of sexual development (up to the midvitellogenic stage, MV) than other temperate anguillids $[35,36]$. Therefore, naturally maturing longfin eels may be suitable for assessing whether artificially maturing Japanese eels progress through oogenesis 'normally', or whether development is aberrant. In the present study, we compared the levels of serum steroids and of ovarian steroidogenic enzyme transcript abundance between artificially maturing Japanese eels and naturally maturing longfin eels at pre- and midvitellogenic stages.

\section{Results}

\subsection{Gonadosomatic Indices in Japanese and Longfin Eels}

Gonadosomatic indices (GSIs) of Japanese and longfin eels at the previtellogenic (PV) stage were $2.3 \pm 0.5 \%$ and $0.7 \pm 0.3 \%$, respectively. Relative gonad weights in wild longfin eels at the MV stage were much higher, having increased to $6.9 \pm 0.3 \%$, a value in between that of artificially maturing Japanese eels in EV $(4.7 \pm 1.4 \%)$ and MV groups $(13.8 \pm 4 \%)$ in the present study (Figure 1).

\subsection{Serum Steroid Hormone Levels in Japanese and Longfin Eels}

Serum T and E2 levels of both eel species at the PV stage were low ( $c a .0 .5 \mathrm{ng} / \mathrm{mL}$ ). In wild longfin eels, T levels had approximately doubled upon reaching the MV stage, averaging $1.1 \mathrm{ng} / \mathrm{mL}$ (Figure 2a). In SPH-injected Japanese eels, T levels similarly averaged 1.0-1.1 ng/mL. However, in eels sampled two days after SPH treatment, T levels were notably higher, reaching $2.3 \pm 0.8 \mathrm{ng} / \mathrm{mL}$ during midvitellogenesis. Similarly, E2 concentrations of MV Japanese eels sampled 2 days after SPH treatment $(3.2 \pm 1.1 \mathrm{ng} / \mathrm{mL})$ were significantly higher than those sampled just prior to SPH treatment $(0.8 \pm 0.1 \mathrm{ng} / \mathrm{mL})$, whereas E2 levels in longfin eels were intermediate $(1.9 \pm 0.02 \mathrm{ng} / \mathrm{mL}$; Figure 2b). Steroid levels in Ringer-injected controls were similar to those in pretreatment Japanese eels (data not shown).

\subsection{Isolation of Five Steroidogenic Enzyme cDNA Fragments from Longfin Eel Ovary}

All of the 12-18 cDNA clones encoding steroidogenic enzymes of longfin eel showed high homology with the nucleotide (amino acid) sequence of steroidogenic enzymes of Japanese eel: cyp11a: 99.2 (98.8)\%, hsd3b: 97.1 (95)\%, cyp17a1: 98.4 (98.5)\%, hsd17b1: $97.2(97) \%$, and cyp19a: 98.8 (99)\%.

\subsection{Expression of Ovarian Steroidogenic Enzymes in Japanese and Longfin Eels}

Cyp11a. Ovarian cyp11a mRNA levels reflected relative gonadal size, with values increasing with increasing GSI (Figure 3a). Interestingly, increases in cyp11a transcript abundance with GSI were approximately linear and showed a very comparable pattern between species; thus, ovarian cyp $11 a$ transcript abundance in artificially maturing Japanese eels and naturally maturing longfin eels superficially fitted the same trendline. Of further note was the observation that cyp11a mRNA levels increased upon pituitary homogenate injections, with increases appearing significant in Japanese eels in midvitellogenesis (Figure 3a).

$H s d 3 b$. Abundance of $h s d 3 b$ transcripts showed a modest nonsignificant trend of increasing as oogenesis proceeded. Furthermore, there was no difference in $h s d 3 b$ mRNA levels between eels sampled just before and two days after pituitary homogenate administration (Figure 3b). 
Cyp17. Changes in cyp17a1 mRNA levels with development showed a comparable pattern to that seen for cyp11a; thus, expression increased with GSI but not dramatically (about two-fold, when comparing previtellogenic and midvitellogenic Japanese eels). The most notable change in ovarian cyp17a1 transcript abundance was seen when comparing midvitellogenic Japanese eels sampled just before and two days after pituitary homogenate treatment (Figure 3c). In contrast, changes in ovarian cyp17a1 mRNA levels over time in both Japanese and longfin eels did not appear to notably differ.

Hsd17b1. Here too, transcript abundance increased as development progressed in a seemingly linear fashion. Moreover, the expression of $h s d 17 b 1$ was comparable in ovaries between Japanese and New Zealand eels. A significant effect of pituitary homogenate treatment in midvitellogenic females was evident (Figure 3d).

Cyp19a. Cyp19a expression was low during the greater part of development in both species, a dramatic increase occurring in midvitellogenic Japanese eels with an average GSI of nearly $14 \%$. A further increase was evident several days after SPH administration (Figure 3e).

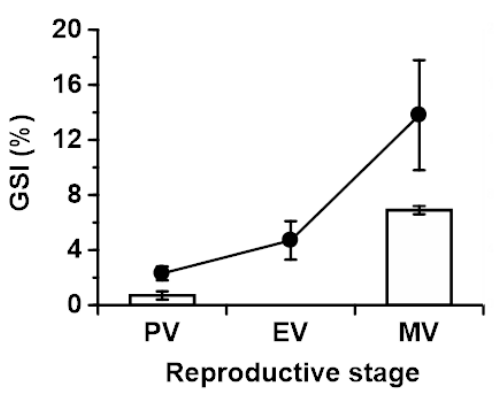

Figure 1. Gonadosomatic index (GSI) of artificially maturing Japanese eels (black circles) and in wild-caught longfin eels (white columns) during vitellogenesis. Ovarian development was classified as: previtellogenic (PV), for follicles $<200 \mu \mathrm{m}$ in diameter (Japanese eel $n=5$, longfin eel $n=9$ ); early vitellogenic (EV) for follicles of 200-400 $\mu \mathrm{m}$ (Japanese eel $\mathrm{n}=8$ ); midvitellogenic (MV) for follicles of 400-600 $\mu \mathrm{m}$ (Japanese eel $\mathrm{n}=10$, longfin eel $\mathrm{n}=16$ ). Values represent mean $\pm \mathrm{SEM}$.

(a)

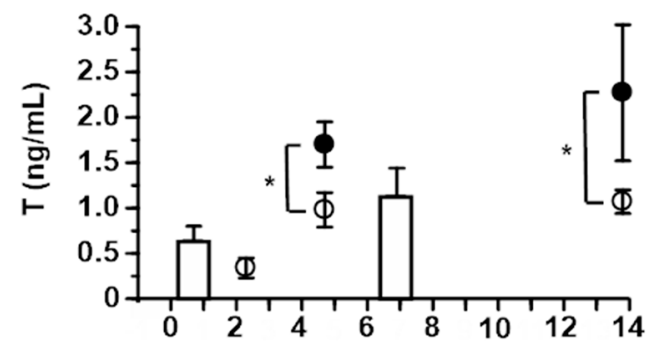

GSI (\%) of experimental group (b)

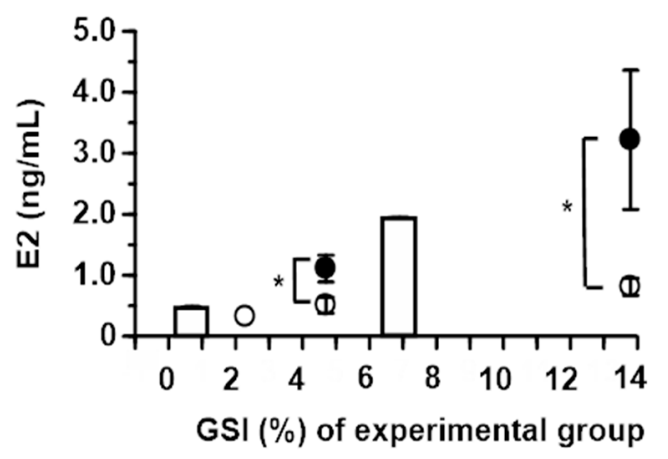

Figure 2. Serum levels of testosterone, T, (a) and estradiol-17 $\beta, \mathrm{E} 2,(\mathbf{b})$ in artificially maturing female Japanese eels (circles) and in wild-caught female longfin eels (white columns) during vitellogenesis. Steroid levels in Japanese eels were determined just prior to (open circles) or 2 days after (black circles) exogenous hormone treatment. Stages of ovarian development are as in Figure 1. Values represent mean \pm SEM. ${ }^{*} P<0.05$ within the same developmental stage. 
(a)

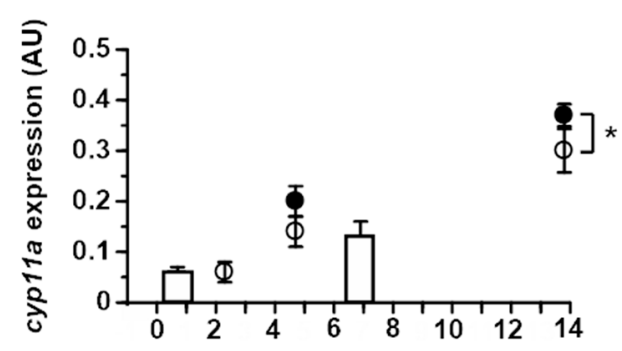

(c)

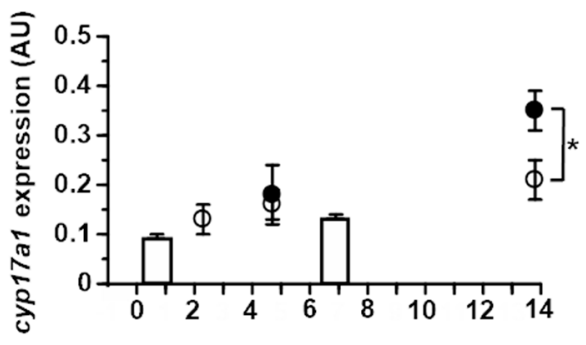

(e)

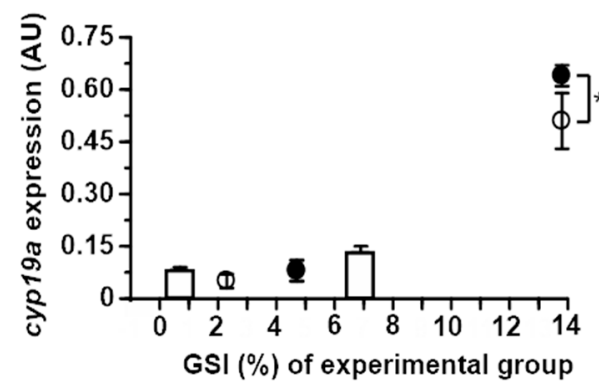

(b)

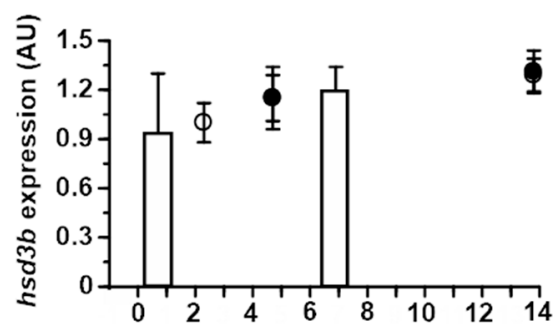

(d)

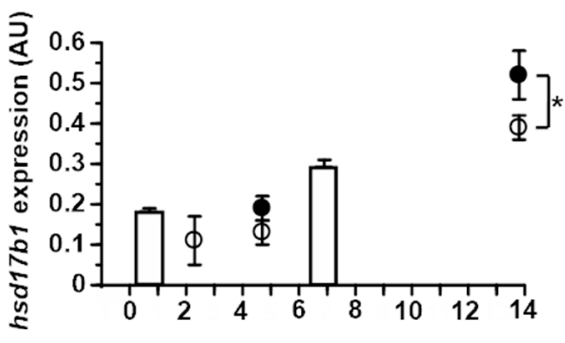

key:

$\Phi$ Japanese eels, before SPH injection

Japanese eels, 2 days after SPH injection

Longfin eels, captured from the wild

Figure 3. Relative mRNA levels (normalized over $\beta$-actin) of P450 side-chain cleavage (cyp11a; (a)), $3 \beta$-hydroxysteroid dehydrogenase (hsd3b; (b)), P450 17 $\alpha$-hydroxylase/C17-20 lyase (cyp17a1; (c)), $17 \beta$-hydroxysteroid dehydrogenase Type-I (hsd17b1; (d)), and P450 aromatase (cyp19a; (e)) in ovaries of Japanese eels (circles) and of wild-caught female longfin eels (white columns). Transcript abundances in Japanese eels were determined just prior to (open circles) or 2 days after (black circles) exogenous hormone treatment. Stages of ovarian development are as in Figure 1. Values represent mean \pm SEM. ${ }^{*} P<0.05$ within the same developmental stage.

\section{Discussion}

Artificial maturation techniques have been applied successfully for production of eel larvae, but yields have been low-in part reflecting low egg quality—which may be impractical for the production of commercial quantities of seedlings in the future [34]. A poor match between oocyte development in artificially maturing freshwater eels and that in maturing eels in their natural environment has been proposed as the most parsimonious explanation for these observations [25,37]. To test this idea, we compared steroid biology between artificially and naturally maturing eels as steroids are key mediators of the gonadotropic signals that drive oogenesis. We employed wild-caught vitellogenic longfin eel as our reference against which artificially maturing Japanese eels were compared because Japanese eels in vitellogenesis are essentially not accessible from the wild. Our findings suggest that ovarian steroidogenic physiology is not obviously different between these two groups of eels during the early stages of vitellogenic growth.

Serum levels of T and E2 increased with gonad size in wild-caught longfin eels, yielding values for migrants (1.1 and $1.9 \mathrm{ng} / \mathrm{mL}$, respectively) that were comparable to those reported previously ( 0.8 and $2.5 \mathrm{ng} / \mathrm{mL}$, respectively) [36]. In artificially maturing Japanese eels in early vitellogenesis, 
concentrations of $\mathrm{T}$ were very similar to those in longfin eels; upon further gonadal growth, $\mathrm{T}$ levels increased, but only to a small extent; thus, the mean T level in Japanese eels around the time of SPH injection showed a trend over time that is not unlike that for longfin eel. However, $\mathrm{T}$ levels in the latter are likely to be controlled within a tight range, whereas, in artificially maturing Japanese eels, $\mathrm{T}$ levels can vary dramatically with the SPH injection schedule. Indeed, in a previous study on artificially maturing Japanese eels, levels of a suite of steroids, including $\mathrm{T}$, varied widely between fish and with time (in days) post-injection [27], findings that reflect the injection regime [38]. A comparable situation exists for E2, levels of which in Japanese eels could crudely fit the longfin eel trendline, but the former is characterized by drastic variation associated with SPH treatment, increasing rapidly following treatment, then steadily decreasing during the ensuing days [27].

Do the fluctuations in serum steroid hormone levels affect the quality of the developing germ cell? This interesting question is one that cannot be answered with the information currently available. Effective maturation protocols that yield high-quality gametes may require regulating the levels of key hormones more tightly to maintain an appropriate environment to support oocyte growth. Such approaches have been successfully used for Japanese eels in the form of sustained-release gonadotropin treatments to induce full maturity, using osmotic minipumps [3] and gelatin and cotton-seed water-in-oil-in-water emulsion [39], respectively. When employing the latter approach, more eggs were spawned than in the 'traditional' hormone-injected group, but the fertility and quality of the resulting eggs were not different. Similarly, the gelatin and oil-seed oil emulsions were considered to perform better than saline-suspended hormone, but details on egg quality were not reported [39].

The expression patterns of steroidogenic enzymes in the ovaries of both groups of eels largely reflected the serum steroid levels; indeed, average expression of cyp $11 a$, cyp17a1, hsd3b, and hsd17b1 showed steadily increasing trends, comparable between both species, as gonad size increased. Similar to what was seen for serum steroids, there was a notable difference in ovarian steroidogenic enzyme gene expression in Japanese eels when comparing between groups sampled just prior ("low" expression) and those sampled two days after injection with SPH ("high" expression). Moreover, variability between replicates, depicted as error around the mean, tended to be markedly greater in artificially maturing Japanese eels than in naturally maturing longfin eels.

The expression pattern of cyp $19 a$ was notably different from that of other steroidogenic enzyme genes evaluated in this study. Thus, ovarian cyp19a mRNA levels were similar between Japanese and longfin eels during early stages of oogenesis, only to rapidly increase by 3-4 fold in Japanese eels as they were stimulated to advance to midvitellogenesis. A rapid increase in expression of ovarian cyp19a during advanced stages of oogenesis in Japanese eels has been reported previously, both on the basis of mRNA levels [40] and on the basis of aromatase activity-based assays (in vitro conversion of androgens into estrogens [40,41]. These findings prompted Ijiri et al. [41] to query whether artificial maturation of Japanese eels leads to abnormal steroidogenesis and aberrant oocyte development. Other freshwater eel species also display a rapid increase in blood E2 levels toward completion of oocyte growth [37,42-45].

Physiological aberrations during oogenesis in artificially maturing eels seem inevitable, especially when considering the drastic variations in steroid levels, which acutely rise and rapidly fall after each $\mathrm{SPH}$ injection. We propose that these acute changes in steroid levels are a reflection of the cyclical presence of injected GTHs which are cleared rapidly from circulation after administration [38]; these GTHs, in turn, are likely to increase the expression of the gene encoding steroidogenic acute regulatory protein (star), a protein that regulates cholesterol transport for subsequent use in steroidogenesis [46]. Indeed, given the strong regulation of the star gene by tropic stimulation in vertebrates [46], including the eel [37], a cyclical SPH-dependent pattern in star expression can be expected to result in the observed rise and fall in levels of steroid substrates. Accordingly, the mismatch between cyp19a mRNA and plasma E2 levels that were seen in Japanese eels sampled just before and those sampled two days post-SPH injection conceivably result from the changes in availability of $\mathrm{T}$ rather than that of the abundance of the enzyme aromatase or its transcript. 
Are the rapid increases in serum E2 at the end of oogenesis themselves truly artefactual and indicative of abnormal steroidogenesis? Reid et al. [37], focusing on the expression of steroidogenic acute regulatory protein (star) in artificially maturing A. australis, proposed that the elevation in plasma levels of E2 in the migratory nucleus stage may be a 'side effect' of the increase in star expression associated with the pre-ovulatory rise in the maturation-inducing progestin, $17 \alpha, 20 \beta$-dihydroxy-4-pregnen-3-one. As such, the increases in levels of E2 were not considered aberrant and could originate from Cyp19a activity in ovarian follicles that constitute later crops of oocytes [37], a possible scenario akin that proposed for seabass [21]. The findings from the present study do not rule out one viewpoint or the other. However, the negative effects of E2 on expression of the apoptosis-suppressor gene $b c l 2$ in the ovarian follicle of artificially maturing eel [47] merits further study on estrogen physiology during induced spawning studies of eel. To conclusively settle this issue, ovarian tissue from mature eels from the wild, such as those caught in recent years near the West Mariana Ridge [23,48,49], should be assessed for blood levels of E2 and ovarian expression of cyp19a.

\section{Materials and Methods}

\subsection{Animals and Sampling Design}

\subsubsection{Sampling of Japanese Eels}

Cultivated female Japanese eels (body weight 500-1200 g), feminized by E2 administration, were obtained from Aichi Fisheries Experimental Station and acclimated to seawater prior to experimentation [50]. Before hormone treatment, five eels (initial controls), all in the previtellogenic (PV) stage, were euthanized by spinal transection after anesthesia in $0.1 \%$ benzocaine. Blood was collected for steroid hormone analysis by radioimmunoassay (see Section 4.3) and ovarian tissue for microscopical examination (Section 4.2) and gene expression analyses by quantitative PCR (Section 4.5). To quantify gonadal development, the gonadosomatic index (GSI) was calculated as the ratio of ovary weight over total body weight and expressed as a percentage.

The remaining eels $(n=21)$ were anesthetized on the day that experimentation commenced (Day 0$)$. Fish then received weekly intramuscular injections of either acetone-dried SPH ( $40 \mu \mathrm{g} / \mathrm{g}$ body weight; $\mathrm{n}=18$ ) suspended in eel Ringer [41] to induce gonadal development, or of eel Ringer only (control Japanese eels; $n=3$ ). To provide insights on the rise and fall of measured endpoints during a weekly injection regime, subsets of the eels were anesthetized after $2-4$ weeks (early vitellogenic, EV; $\mathrm{n}=8$ ) and after 5-7 weeks of treatment with SPH (midvitellogenic; MV; $\mathrm{n}=10$ ) or Ringer (PV; $\mathrm{n}=3$ ). Blood was sampled by syringe from the caudal vasculature, and ovarian biopsies were obtained as described previously [42]. These eels were killed by anesthetic overdose after $2-4$ weeks $(E V ; n=8)$ and after 5-7 weeks of treatment with SPH (MV; $\mathrm{n}=10)$ or Ringer $(\mathrm{PV} ; \mathrm{n}=3)$; samples from remaining eels were collected two days later. Blood and gonad samples were collected for analysis, as described above. Experiments with eels were performed according to the recommendations of the ethical guidelines of Hokkaido University approved by the Institutional Animal Care and Use Committee of Hokkaido University.

\subsubsection{Sampling of Longfin Eels}

Female longfin eels (body weight 729-9600 $\mathrm{g}, \mathrm{n}=25$ ) were caught by fyke net, set overnight, in Lake Ellesmere, New Zealand, during the austral autumn. Fish were transported to the field laboratory $(2-4 \mathrm{~h})$ and held in natural spring water $\left(12^{\circ} \mathrm{C}\right)$ until euthanasia by anesthetic overdose for collection of blood and ovarian tissue that same day. The same analyses as for Japanese eels were performed on these samples; in addition, molecular cloning of longfin eel steroidogenic enzyme cDNAs was conducted (Section 4.4). Animals were staged as PV $(n=9)$ or MV $(n=16)$ on the basis of histological observations; details on pituitary gonadotropin subunit mRNA levels in these fish were previously published [51]. 


\subsection{Macroscopical Analyses}

Follicles were gently removed from ovarian tissue in Ringer and the mean diameters of the largest size class were determined using a binocular microscope. Follicles were staged on the basis of Kazeto et al. [52] as PV $<200 \mu \mathrm{m}, \mathrm{EV}<200-400 \mu \mathrm{m}$, and MV $<400-600 \mu \mathrm{m}$ in diameter.

\subsection{Radioimmunoassay}

Collected blood was centrifuged at $3000 \times g$ for $10 \mathrm{~min}$ at $4{ }^{\circ} \mathrm{C}$ and serum stored at $-30{ }^{\circ} \mathrm{C}$ until use in radioimmunoassay. E2 and T were measured employing the same antisera (Cosmo Bio FKA-235 and FKA-102) and methodology as reported in Matsubara et al. [27] The minimum levels of detectability were $30 \mathrm{pg} / \mathrm{mL}$ for both steroids.

\subsection{Isolation of Partial Steroidogenic Enzyme cDNAs from Longfin Eel Ovary}

Ovarian tissues were snap-frozen in liquid nitrogen and kept at $-80{ }^{\circ} \mathrm{C}$ until use. Total RNA was extracted and first-strand cDNAs synthesized according to Matsubara et al. [28] For molecular cloning of partial cDNAs encoding ovarian steroidogenic enzymes from longfin eels, forward and reverse primers (Table 1) were designed based on the nucleotide sequences of Japanese eel cyp11a (AY654741), hsd3b (AF063835), cyp17a1 (AY498619), hsd17b1 (AY498620), and cyp19a (AY540622).

Complementary DNA was amplified by polymerase chain reaction using 35 cycles of $94{ }^{\circ} \mathrm{C}$ for $30 \mathrm{~s}, 55^{\circ} \mathrm{C}$ for $30 \mathrm{~s}$, and $72{ }^{\circ} \mathrm{C}$ for $30 \mathrm{~s}$ on an automated thermal cycler (Gene Amp PCR System 9600, PE Applied Biosystems, Foster City, CA, USA). PCR products were subcloned into the pCR2.1 vector (Invitrogen, Carlsbad, CA, USA) and sequenced using an ABI 373 DNA sequencer (Applied Biosystems, Foster City, CA, USA ). The cDNA sequences have been uploaded onto GenBank with the following accession numbers: LC032023 (cyp11a), LC032021 (hsd3b), LC032024 (cyp17a1), LC031820 (hsd17b1), and LC032022 (cyp19a).

Table 1. PCR primer sequences for amplification of partial cDNAs encoding P450 side-chain cleavage (cyp11a), 3 $\beta$-hydroxysteroid dehydrogenase ( $h s d 3 b)$, P450 17 $\alpha$-hydroxylase/C17-20 lyase (cyp17a1), $17 \beta$-hydroxysteroid dehydrogenase Type-I ( $h s d 17 b 1)$, and P450 aromatase (cyp19a) from longfin eel ovary.

\begin{tabular}{|c|c|c|}
\hline Gene & Primer & Sequence \\
\hline \multirow{2}{*}{ Cyp $11 a$} & sense & 5'-GTTCATCGTATCATGCTCAAC-3' \\
\hline & antisense & 5'-AGTCCACСТСТССТATGTTG-3' \\
\hline \multirow{2}{*}{$h s d 3 b$} & sense & 5'-TGTGGCTTCCTGGGAGAGA-3' \\
\hline & antisense & 5'-GTACATCTACGGCGATGG-3 \\
\hline \multirow{2}{*}{ cyp17a1 } & sense & 5'-ATAGTGGACACCGTGGCCAAGGA-3 \\
\hline & antisense & 5'-CTGCAGGACCACCCCAAATTTGC-3' \\
\hline \multirow{2}{*}{$h s d 17 b 1$} & sense & 5'-AGAGTGGTGCTGATCACG-3' \\
\hline & antisense & 5'-TGTGAGAGTTTGGCTATTCTC-3' \\
\hline \multirow{2}{*}{ cyp19a } & sense & 5'-TGGCAGACAGTTCTGATCA-3' \\
\hline & antisense & 5'-AACCGAAGGGCTGGAAGAAA-3' \\
\hline
\end{tabular}

\subsection{Real-Time Quantitative PCR ( $q P C R)$}

Using Primer Express Software ver. 1.0 (Applied Biosystems, Foster City, CA, USA), specific primers and TaqMan molecular probes were designed across regions of the steroidogenic enzyme nucleotide sequences that exactly matched between both eel species. Sequences of primers and probes (Applied Biosystems, Foster City, CA, USA) for qPCR analysis of $h s d 3 b$, $h s d 17 b 1$, and cyp $19 a$ (Matsubara et al. [28]), and $\beta$-actin [51] were previously reported. The qPCR probe for cyp11a, yielding an amplicon of $82 \mathrm{bp}$, was redesigned, as follows:

probe 5'(FAM)-CCACTCGATTGGTCCTAAACAAGCAAGTAAT-3'(TAMURA).

Primers and probe for cyp $17 a 1$, yielding an amplicon of $131 \mathrm{bp}$, were redesigned, as follows: 


\section{sense 5'-TTAAGCGACAGAGGCAACCT-3' \\ antisense 5 '-CCAACTGTGTACTCCCCGAT-3 \\ probe 5'(FAM)-CCGTATCTTGAGGCCACCATCAGG-3'(TAMURA).}

Quantitative PCR analyses were performed as described by Matsubara et al. [28] The linear range of the standard curves fell within $10^{1}-10^{7}$ copies and correlation coefficients were more than 0.995 for all curves. The intra-assay coefficient of variation was less than $8 \%$ ( $n=3$ for all assays). Inter-assay coefficients of variation were less than $10 \%$ (all assays: $n=3$ ).

\subsection{Statistical Analysis}

Data are presented as means \pm SEM. Data on GSI, serum steroid levels, and mRNA levels of ovarian steroidogenic enzymes (normalized over those of $\beta$-actin; see Saito et al. [51]) in artificially maturing Japanese eels and wild-caught longfin eels were analyzed using a one-way ANova followed by Fisher's Least Significant Difference post hoc test. Significance was accepted at $P<0.05$.

\section{Conclusions}

In conclusion, the present study has provided compelling evidence to suggest that early stages of gonadotropin-dependent oocyte growth may not differ dramatically between wild, naturally maturing longfin eels from New Zealand and artificially maturing Japanese eels. The key differences in terms of steroid biology between both groups seem to center around the drastic acute fluctuations in steroid levels in serum and the accompanying expression of steroidogenic enzymes in the ovary of Japanese eels. It remains unclear whether these fluctuations affect germ cell quality, but they underline the need for further refinements of induced spawning protocols in freshwater eels.

Author Contributions: Conceptualization, H.M., P.M.L., Y.K., H.O., S.I., T.H., G.Y., S.A., and K.Y.; data curation, H.M. and P.M.L.; formal analysis, H.M. and P.M.L.; funding acquisition, H.M. and P.M.L.; investigation, H.M., P.M.L., Y.K., H.O., and S.I.; resources, P.M.L., Y.K., H.O., S.I, G.Y., S.A., and K.Y.; supervision, T.H., G.Y., S.A., and K.Y.; writing—original draft, H.M. and P.M.L.; writing—review and editing, P.M.L., T.H., G.Y., S.A., and K.Y.

Funding: This study was supported by grants from the Ministry of Education, Science and Culture, Japan; the Fisheries Agency, Japan; and the Japan Society for the Promotion of Science for Young Scientists and for Research for Future Program (00J07078,05J00244) to H.M.

Acknowledgments: The authors thank the 1998-2003 Eel Research Group at Hokkaido University's Faculty of Fisheries for encouragement. We are grateful to the staff of the Aichi Prefectural Inland Water Fisheries Experiment Station for providing the broodstock of the eel.

Conflicts of Interest: The authors declare no conflict of interest.

\section{References}

1. Nagahama, Y.; Yoshikuni, M.; Yamashita, M.; Tokumoto, T.; Katsu, Y. Regulation of Oocyte Growth and Maturation in Fish. Curr. Top. Dev. Biol. 1995, 30, 103-145. [PubMed]

2. Lubzens, E.; Young, G.; Bobe, J.; Cerdà, J. Oogenesis in teleosts: How fish eggs are formed. Gen. Comp. Endocrinol. 2010, 165, 367-389. [CrossRef] [PubMed]

3. Kagawa, H. Oogenesis in teleost fish. Aqua-BioSci. Monogr. 2013, 6, 99-127. [CrossRef]

4. Wallace, R.A.; Jared, D.W.; Kohler, P.O.; Grimley, P.M.; O’Malley, B.W. Estrogen Induces Lipophosphoprotein in Serum of Male Xenopus laevis. Science 1968, 160, 91-92. [CrossRef] [PubMed]

5. Wallace, R.A. A comprehensive synthesis. In Developmental Biology Volume I; Browder, L.W., Ed.; Plenum Press: New York, NY, USA, 1985; pp. 127-177.

6. Thomas, P. Rapid steroid hormone actions initiated at the cell surface and the receptors that mediate them with an emphasis on recent progress in fish models. Gen. Com. Endocrinol. 2012, 175, 367-383. [CrossRef] [PubMed]

7. Takahashi, M.; Tanaka, M.; Sakai, N.; Adachi, S.; Miller, W.L.; Nagahama, Y. Rainbow trout ovarian cholesterol side-chain cleavage cytochrome P450 (P450scc). cDNA cloning and mRNA expression during oogenesis. FEBS Lett. 1993, 319, 45-48. [CrossRef] 
8. Nunez, S.; Trant, J.M. Isolation of the putative cDNA encoding cholesterol side chain cleavage cytochrome P450 (CYP11A) of the southern stingray (Dasyatis americana). Gene 1997, 187, 123-129. [CrossRef]

9. Sakai, N.; Tanaka, M.; Takahashi, M.; Fukada, S.; I Mason, J.; Nagahama, Y. Ovarian 3 beta-hydroxysteroid dehydrogenase/delta 5-4-isomerase of rainbow trout: Its cDNA cloning and properties of the enzyme expressed in a mammalian cell. FEBS Lett. 1994, 350, 309-313. [CrossRef]

10. Núñez, S.; Trant, J. Molecular biology and enzymology of elasmobranch $3 \beta$-hydroxysteroid dehydrogenase. Fish Physiol. Biochem. 1998, 19, 293-304. [CrossRef]

11. Sakai, N.; Tanaka, M.; Adachi, S.; Miller, W.L.; Nagahama, Y. Rainbow trout cytochrome P-450c17 (17 alpha-hydroxylase/17,20-lyase). cDNA cloning, enzymatic properties and temporal pattern of ovarian P-450c17 mRNA expression during oogenesis. FEBS Lett. 1992, 301, 60-64. [CrossRef]

12. Trant, J.M. Isolation and characterization of the cDNA encoding the spiny dogfish shark (Squalus acanthias) form of cytochrome P450c17. J. Exp. Zool. 1995, 272, 25-33. [CrossRef] [PubMed]

13. Kazeto, Y.; Ijiri, S.; Matsubara, H.; Adachi, S.; Yamauchi, K. Cloning of $17 \beta$-Hydroxysteroid Dehydrogenase-I cDNAs from Japanese Eel Ovary. Biochem. Biophys. Res. Commun. 2000, 279, 451-456. [CrossRef] [PubMed]

14. Tanaka, M.; Telecky, T.M.; Fukada, S.; Adachi, S.; Chen, S.; Nagahama, Y. Cloning and sequence analysis of the cDNA encoding P-450 aromatase (P450arom) from a rainbow trout (Oncorhynchus mykiss) ovary; relationship between the amount of P450arom mRNA and the production of oestradiol-17 beta in the ovary. J. Mol. Endocrinol. 1992, 8, 53-61. [CrossRef] [PubMed]

15. Trant, J.M. Isolation and Characterization of the cDNA Encoding the Channel Catfish (Ictalurus punctatus) Form of Cytochrome P450arom. Gen. Comp. Endocrinol. 1994, 95, 155-168. [CrossRef]

16. Zhou, L.-Y.; Wang, D.-S.; Kobayashi, T.; Yano, A.; Paul-Prasanth, B.; Suzuki, A.; Sakai, F.; Nagahama, Y. A Novel Type of P450c17 Lacking the Lyase Activity Is Responsible for C21-Steroid Biosynthesis in the Fish Ovary and Head Kidney. Endocrinology 2007, 148, 4282-4291. [CrossRef]

17. Su, T.; Ijiri, S.; Kanbara, H.; Hagihara, S.; Wang, D.-S.; Adachi, S. Characterization and expression of cDNAs encoding P450c17-II (cyp17a2) in Japanese eel during induced ovarian development. Gen. Comp. Endocrinol. 2015, 221, 134-143. [CrossRef]

18. Kumar, R.S.; Trant, J.M.; Ijiri, S. Changes in the Expression of Genes Encoding Steroidogenic Enzymes in the Channel Catfish (Ictalurus punctatus) Ovary Throughout a Reproductive Cycle1. Biol. Reprod. 2000, 63, 1676-1682. [CrossRef]

19. Ings, J.S.; Van Der Kraak, G.J. Characterization of the mRNA expression of StAR and steroidogenic enzymes in zebrafish ovarian follicles. Mol. Reprod. Dev. 2006, 73, 943-954. [CrossRef]

20. Nakamura, I.; Evans, J.C.; Kusakabe, M.; Nagahama, Y.; Young, G. Changes in steroidogenic enzyme and steroidogenic acute regulatory protein messenger RNAs in ovarian follicles during ovarian development of rainbow trout (Oncorhynchus mykiss). Gen. Comp. Endocrinol. 2005, 144, 224-231. [CrossRef]

21. Rocha, A.; Zanuy, S.; Carrillo, M.; Gómez, A. Seasonal changes in gonadal expression of gonadotropin receptors, steroidogenic acute regulatory protein and steroidogenic enzymes in the European sea bass. Gen. Comp. Endocrinol. 2009, 162, 265-275. [CrossRef]

22. Tsukamoto, K. Oceanic biology: Spawning of eels near a seamount. Nature 2006, 439, 929. [CrossRef] [PubMed]

23. Chow, S.; Kurogi, H.; Mochioka, N.; Kaji, S.; Okazaki, M.; Tsukamoto, K. Discovery of mature freshwater eels in the open ocean. Fish. Sci. 2009, 75, 257-259. [CrossRef]

24. Yamamoto, K.; Yamauchi, K. Sexual maturation of Japanese eel and production of eel larvae in the aquarium. Nature 1974, 251, 220-222. [CrossRef] [PubMed]

25. Adachi, S.; Ijiri, S.; Kazeto, Y.; Yamauchi, K. Oogenesis in the Japanese eel, Anguilla japonica. In Eel Biology; Aida, K., Tsukamoto, K., Yamauchi, K., Eds.; Springer: Tokyo, Japan, 2003; pp. 301-317. 
26. Burgerhout, E.; Minegishi, Y.; Brittijn, S.A.; De Wijze, D.L.; Henkel, C.V.; Jansen, H.J.; Spaink, H.P.; Dirks, R.P.; Thillart, G.E.V.D. Changes in ovarian gene expression profiles and plasma hormone levels in maturing European eel (Anguilla anguilla); Biomarkers for broodstock selection. Gen. Comp. Endocrinol. 2016, 225, 185-196. [CrossRef] [PubMed]

27. Matsubara, H.; Lokman, P.M.; Kazeto, Y.; Adachi, S.; Yamauchi, K. Serum steroid profiles in artificially maturing female Japanese eel, Anguilla japonica. Aquaculture 2005, 243, 393-402. [CrossRef]

28. Matsubara, H.; Kazeto, Y.; Ijiri, S.; Hirai, T.; Adachi, S.; Yamauchi, K. Changes in mRNA levels of ovarian steroidogenic enzymes during artificial maturation of Japanese eel Anguilla japonica. Fish. Sci. 2003, 69, 979-988. [CrossRef]

29. Tanaka, H.; Kagawa, H.; Ohta, H. Production of leptocephali of Japanese eel (Anguilla japonica) in captivity. Aquaculture 2001, 201, 51-60. [CrossRef]

30. Tanaka, H. Techniques for larval rearing. In Eel Biology; Aida, K., Tsukamoto, K., Yamauchi, K., Eds.; Springer: Tokyo, Japan, 2003; pp. 427-434.

31. Ohta, H.; Higashimoto, Y.; Koga, S.; Unuma, T.; Nomura, K.; Tanaka, H.; Kagawa, H.; Arai, K. Occurrence of spontaneous polyploids from the eggs obtained by artificial induction of maturation in the Japanese eel (Anguilla japonica). Fish Physiol. Biochem. 2003, 28, 517-518. [CrossRef]

32. Kurokawa, T.; Okamoto, T.; Gen, K.; Uji, S.; Murashita, K.; Unuma, T.; Nomura, K.; Matsubara, H.; Kim, S.H.; Ohta, H.; et al. Effect of the water temperature on morphological deformities in cultured larvae of Japanese eel Anguilla japonica at competition of yolk absorption. J. World Aquac. Soc. 2008, 39, 726-735. [CrossRef]

33. Okamura, A.; Yamada, Y.; Mikawa, N.; Horie, N.; Tsukamoto, K. Effect of salinity on occurrence of notochord deformities in Japanese eel Anguilla japonica larvae. Aquac. Int. 2016, 24, 549-555. [CrossRef]

34. Okamura, A.; Horie, N.; Mikawa, N.; Yamada, Y.; Tsukamoto, K. Recent advances in artificial production of glass eels for conservation of anguillid eel populations. Ecol. Freshwat. Fish 2014, 23, 95-110. [CrossRef]

35. Todd, P.R. Morphometric changes, gonad histology, and fecundity estimates in maturing New Zealand freshwater eels. N. Z. J. Mar. Freshw. Res. 1981, 15, 155-170. [CrossRef]

36. Lokman, P.; Young, G. Gonad histology and plasma steroid profiles in wild New Zealand freshwater eels (Anguilla dieffenbachii and A. australis) before and at the onset of the natural spawning migration. II. Males. Fish Physiol. Biochem. 1998, 19, 339-347. [CrossRef]

37. Reid, P.M.; Divers, S.L.; Zadmajid, V.; Alqaisi, K.M.; Lokman, P.M. Steroidogenic acute regulatory protein transcript abundance in the eel, Anguilla australis: Changes during the induced reproductive cycle and effects of follicle-stimulating hormone during previtellogenesis. J. Steroid Biochem. Mol. Biol. 2013, 138, 464-470. [CrossRef] [PubMed]

38. Eding, E.H.; van Zanten, G.H.; Bongers, A.B.J.; Richter, C.J.J.; Lambert, J.G.D.; Goos, H.J.T.h. Induction of ovarian development in European eel (Anguilla anguilla) with low dosages of carp pituitary suspension. In Proceedings of the Fourth International Symposium on the Reproductive Physiology of Fish; Scott, A.P., Sumpter, J.P., Kime, D.E., Rolfe, M.S., Eds.; University of East Anglia: Norwich, UK, 1991; p. 321.

39. Sato, N.; Kawazoe, I.; Suzuki, Y.; Aida, K. Development of an emulsion prepared with lipophilized gelatin and its application for hormone administration in the Japanese eel Anguilla japonica. Fish Physiol. Biochem. 1997, 17, 171-178. [CrossRef]

40. Ijiri, S.; Kazeto, Y.; Lokman, P.M.; Adachi, S.; Yamauchi, K. Characterization of a cDNA encoding $\mathrm{P}$-450aromatase (P450arom) from Japanese eel ovary and its expression in ovarian follicles during induced ovarian development. Gen. Comp. Endocrinol. 2003, 130, 193-203. [CrossRef]

41. Ijiri, S.; Kazeto, Y.; Takeda, N.; Chiba, H.; Adachi, S.; Yamauchi, K. Changes in serum steroid hormones and steroidogenic ability of ovarian follicles during artificial maturation of cultivated Japanese eel, Anguilla japonica. Aquaculture 1995, 135, 3-16. [CrossRef]

42. Lokman, P.M.; Wass, R.T.; Suter, H.C.; Scott, S.G.; Judge, K.F.; Young, G. Changes in steroid hormone profiles and ovarian histology during salmon pituitary-induced vitellogenesis and ovulation in female New Zealand longfinned eels, Anguilla dieffenbachii gray. J. Exp. Zool. 2001, 289, 119-129. [CrossRef]

43. Pérez, L.M.; Peñaranda, D.S.; Dufour, S.; Baloche, S.; Palstra, A.; Thillart, G.V.D.; Asturiano, J.F. Influence of temperature regime on endocrine parameters and vitellogenesis during experimental maturation of European eel (Anguilla anguilla) females. Gen. Comp. Endocrinol. 2011, 174, 51-59. [CrossRef] 
44. Nguyen, A.T.; Chia, J.H.Z.; Kazeto, Y.; Lokman, P.M. Expression of gonadotropin subunit and gonadotropin receptor genes in wild female New Zealand shortfinned eel (Anguilla australis) during yellow and silver stages. Gen. Comp. Endocrinol. 2019, 272, 83-92. [CrossRef]

45. Jéhannet, P.; Kruijt, L.; Damsteegt, E.; Swinkels, W.; Heinsbroek, L.; Lokman, P.; Palstra, A. A mechanistic model for studying the initiation of anguillid vitellogenesis by comparing the European eel (Anguilla anguilla) and the shortfinned eel (A. australis). Gen. Comp. Endocrinol. 2019, 279, 129-138. [CrossRef] [PubMed]

46. Stocco, D.M. Steroidogenic acute regulatory (StAR) protein: what's new? BioEssays 1999, 21, 768-775. [CrossRef]

47. Lin, T.-T.; Lan, P.-C.; Hsieh, Y.-J.; Wang, Y.-S. Estrogen suppresses Bcl2 expression through DNMT1 in Japanese eel ovarian follicle. Reproduction 2019, 158, 291-302. [CrossRef] [PubMed]

48. Kurogi, H.; Okazaki, M.; Mochioka, N.; Jinbo, T.; Hashimoto, H.; Takahashi, M.; Tawa, A.; Aoyama, J.; Shinoda, A.; Tsukamoto, K.; et al. First capture of post-spawning female of the Japanese eel Anguilla japonica at the southern West Mariana Ridge. Fish. Sci. 2011, 77, 199-205. [CrossRef]

49. Aoyama, J.; Watanabe, S.; Miller, M.J.; Mochioka, N.; Otake, T.; Yoshinaga, T.; Tsukamoto, K. Spawning Sites of the Japanese Eel in Relation to Oceanographic Structure and the West Mariana Ridge. PLoS ONE 2014, 9, e88759. [CrossRef]

50. Ijiri, S.; Kayaba, T.; Takeda, N.; Tachiki, H.; Adachi, S.; Yamauchi, K. Pretreatment Reproductive Stage and Oocyte Development Induced by Salmon Pituitary Homogenate in the Japanese Eel Anguilla japonica. Fish. Sci. 1998, 64, 531-537. [CrossRef]

51. Saito, K.; Lokman, P.M.; Young, G.; Ozaki, Y.; Matsubara, H.; Okumura, H.; Kazeto, Y.; Yoshiura, Y.; Aida, K.; Adachi, S.; et al. Follicle-stimulating hormone, luteinizing hormone and glycoprotein hormone subunit mRNA levels in artificially maturing Japanese eel Anguilla japonica and naturally maturing New Zealand longfinned eel Anguilla dieffenbachia. Fish. Sci. 2003, 69, 146-153. [CrossRef]

52. Kazeto, Y.; Ijiri, S.; Todo, T.; Adachi, S.; Yamauchi, K. Molecular Cloning and Characterization of Japanese Eel Ovarian P450c17 (CYP17) cDNA. Gen. Comp. Endocrinol. 2000, 118, 123-133. [CrossRef]

(C) 2019 by the authors. Licensee MDPI, Basel, Switzerland. This article is an open access article distributed under the terms and conditions of the Creative Commons Attribution (CC BY) license (http://creativecommons.org/licenses/by/4.0/). 